\title{
DMSP-lyase activity in a spring phytoplankton bloom off the Dutch coast, related to Phaeocystis sp. abundance
}

\author{
J. Stefels ${ }^{1}$, L. Dijkhuizen ${ }^{2}$, W. W. C. Gieskes ${ }^{1}$ \\ ${ }^{1}$ University of Groningen, Dept of Marine Biology, PO Box 14, 9750 AA Haren, The Netherlands \\ ${ }^{2}$ University of Groningen, Dept of Microbiology, PO Box 14, 9750 AA Haren, The Netherlands
}

\begin{abstract}
An enzyme assay for measuring dimethylsulfoniopropionate (DMSP)-lyase activity was applied to natural sea water samples taken during the 1993 spring bloom off the Dutch coast. When relating the measured DMSP-lyase activity to the most abundant algal species found during the cruise, a significant correlation with Phaeocystis sp. numbers $\left(\mathrm{r}^{2}=0.9660, \mathrm{n}=23\right)$ was observed, but not with any of the other species present, or with total diatom numbers, total diatom biovolume or total protein. The calculated dimethyl sulfide (DMS) production by Phaeocystis sp. in a typical spring bloom off the Dutch coast appeared to be 1.5 to 4.5 times higher than the DMS loss due to flux to the atmosphere and photochemical oxidation. The results indicate that the alga Phaeocystis sp. has a very active DMSPlyase, specific for this species, that was potentially responsible for the conversion of DMSP to DMS in the area investigated, leaving 35 to $75 \%$ of DMS for bacterial consumption.
\end{abstract}

KEY WORDS: Dimethylsulfide - Dimethylsulfoniopropionate DMSP-lyase - Phaeocystis sp.

\section{INTRODUCTION}

The volatile organosulfur compound dimethylsulfide (DMS) has generated much interest in the past decades because of its possible role in the biological regulation of the climate (Charlson et al. 1987, Andreae 1990, Fitzgerald 1991, Malin et al. 1992, Lawrence 1993, Charlson \& Wigley 1994, Malin et al. 1994). Oceans are the main source of DMS to the atmosphere. In the atmosphere, DMS is oxidized to form aerosols, thereby influencing cloud albedo and subsequently climate. In sea water, DMS is produced from dimethylsulfoniopropionate (DMSP), a compound that is found in several marine micro- and macroalgae (Reed 1983, Keller et al. 1989, Blunden et al. 1992), and is suggested to serve mainly as an osmoprotectant (Vairavamurthy et al. 1985, Dickson \& Kirst 1987a, b). Conversion of DMSP into DMS and acrylic acid is thought to take place after its release from the cells, when part of the dissolved DMSP is cleaved through enzymatic activity. DMSPlyase activity has been found in crude extracts of the macrophyte Polysiphonia lanosa (Cantoni \& Anderson 1956) and of the heterotrophic dinoflagellate Gyro- dinium cohnii (Ishida 1968), and more recently also in whole cells of axenic Phaeocystis sp. cultures (Stefels \& van Boekel 1993). The bulk enzymatic conversion of DMSP to DMS in natural sea water samples has, until now, been attributed to bacterial lyase activity (Kiene 1990, 1992, Kiene \& Service 1991). Zooplankton has also been suggested to be directly or indirectly involved in the conversion of DMSP to DMS and acrylate (Dacey \& Wakeham 1986, Leck et al. 1990). In the latter 2 studies, the possibility could not be excluded that zooplankton only played an intermediate role by releasing DMSP from the algae grazed upon due to sloppy feeding or digestion, making DMSP available for bacterial or algal enzymes. Wolfe et al. (1994) reported on the impact of grazing by a herbivorous dinoflagellate on the fate of intracellular DMSP of Emiliania huxleyi. They found that 30 to $70 \%$ of the lost algal DMSP could not be traced back in the form of dissolved DMSP or DMS. An alternative pathway for DMSP decomposition has been postulated by Kiene \& Service (1991). In samples from estuarine waters off Georgia, USA, they found that only $28 \%$ of the DMSP consumed could be traced back as DMS; demethyla- 
tion was suggested to be an alternative route for DMSP metabolism. These authors also suggested a close coupling between the production and consumption of DMS. Kiene \& Bates (1990) found that microbial DMS consumption was generally 10 times faster than the flux of DMS to the atmosphere.

Although attempts to quantify the processes mentioned above have been scarce, with today's knowledge it is tempting to believe that, on a global scale, only a small part of the DMSP-sulfur will ever reach the atmosphere (Matrai \& Keller 1993, Bates et al. 1994). On the other hand, the relative magnitude of the processes involved may differ greatly, depending on the composition of the plankton assemblage (including bacteria, phytoplankton and zooplankton), which, in its turn, differs from season to season and from place to place. This seasonality and locality of the processes involved can temporarily result in relatively large fluxes of DMS compared to the DMSP concentration in the water. Therefore, the possibility that blooms of specific algal species provide the main part of the DMS flux to the atmosphere in a short time span is a phenomenon worth investigating.

An interesting species in this respect is Phaeocystis $\mathrm{sp}$. This colony-forming alga contains large amounts of DMSP (Keller et al. 1989, Stefels \& van Boekel 1993), is known to form excessive blooms in temperate as well as polar regions (Cadée \& Hegeman 1986, Smith et al. 1991, Davidson \& Marchant 1992), and has gained interest in DMS studies (Barnard et al. 1984, Gibson et al. 1990, Baumann et al. 1994, Liss et al. 1994). Phaeocystis sp. is one of the species which benefits strongly from eutrophication in the North Sea (Lancelot et al. 1987, Riegman et al. 1992). Stefels \& van Boekel (1993) showed that Phaeocystis sp. is able to convert dissolved DMSP enzymatically, and that this enzyme activity is approximately in the same range as bacterial production of DMS from DMSP, reported in the literature. In their study the possibility that DMSP conversion was a secondary effect of an enzyme not specific to DMSP nor specific for Phaeocystis sp. could not be excluded, and the actual contribution of Phaeocystis $\mathrm{sp}$. to DMS production in the field therefore remained to be investigated.

The objective of the present study was to investigate whether there is a relationship between the potential enzymatic conversion of DMSP to DMS in natural waters and the presence of Phaeocystis sp. or any other algal species. To this end, a DMSP-lyase enzyme assay was applied to natural sea water samples off the Dutch coast, taken during the spring bloom of 1993. The potential contribution of Phaeocystis sp. to DMS production was calculated and compared to the main abiotic loss factors, fluxes of DMS to the atmosphere and photochemical oxidation.

\section{MATERIALS AND METHODS}

Sample collection. During the spring phytoplankton bloom of 1993, surface water samples were taken with a bucket off the Dutch coast from aboard the RV 'Pelagia' (Fig. 1). In order to relate DMSP-lyase activity to specific groups in the plankton, the plankton assemblage was separated into size fractions. The particulate matter of 350 to $1000 \mathrm{ml}$ was fractionated and concentrated qualitatively. To prevent disruption of cells the $>100 \mu \mathrm{m}$ fraction was gently separated and concentrated using a $100 \mu \mathrm{m}$ mesh sieve in the bottom of a plastic beaker. The $<100 \mu \mathrm{m}$ fraction was run under gravity only - through a cascade of tangential reversed-flow filters using polycarbonate filters with pore diameters of 10,2 and $0.2 \mu \mathrm{m}$ respectively (Fig. 2).

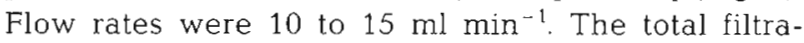
tion time never exceeded $1 \mathrm{~h}$. After filtration, the different fractions were gently shaken, to resuspend part of the cells that had stuck to the filter, and tapped from the chambers underneath the filters; volumes of the fractions were 25 to $30 \mathrm{ml}$. Of all fractions $2 \mathrm{ml}$ subsamples were taken for cell counts, fixed with $1 \%$ buffered formaldehyde and stored at $4^{\circ} \mathrm{C}$. To the remaining fraction $1 \mathrm{ml} 100 \mathrm{mM}$ Tris/ $\mathrm{HCl}$ buffer $(\mathrm{pH} 8)$ with $125 \mathrm{mM}$ dithiothreitol (DTT) was added and stored at $-80^{\circ} \mathrm{C}$ for further analyses in the laboratory. Storage always resulted in loss of activity, but experiments showed that storage at $-80^{\circ} \mathrm{C}$ gave 2 times higher DMSP-lyase activity than storage at $-20^{\circ} \mathrm{C}$. An aliquot of the $<0.2 \mu \mathrm{m}$ fraction was taken for analyses

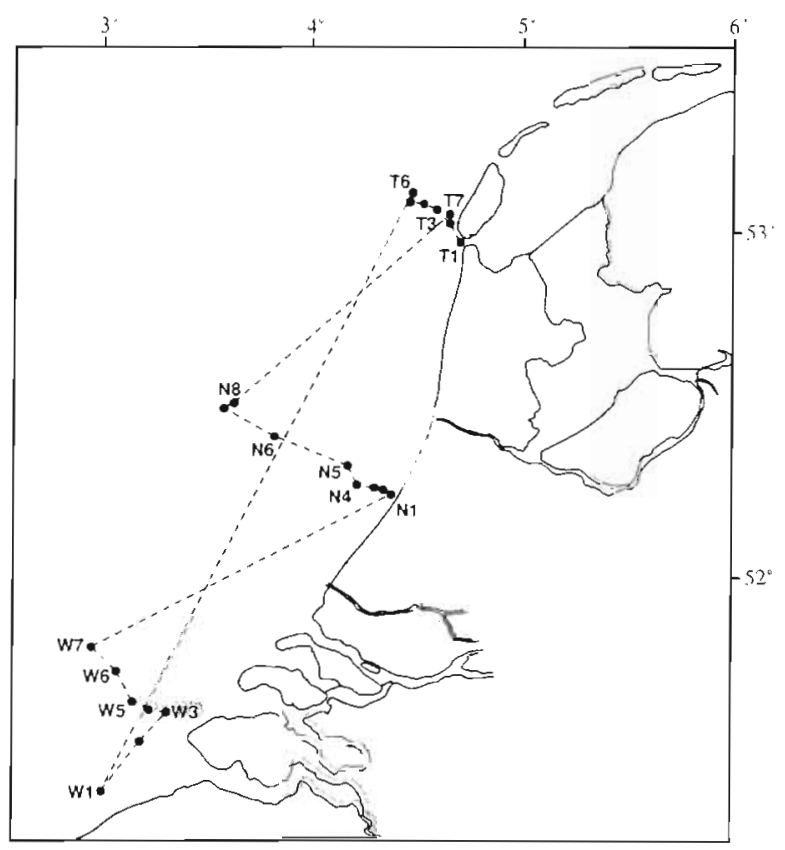

Fig. 1. Locations of the sampling stations along the cruise track of RV 'Pelagia', 13 to 16 April 1993 


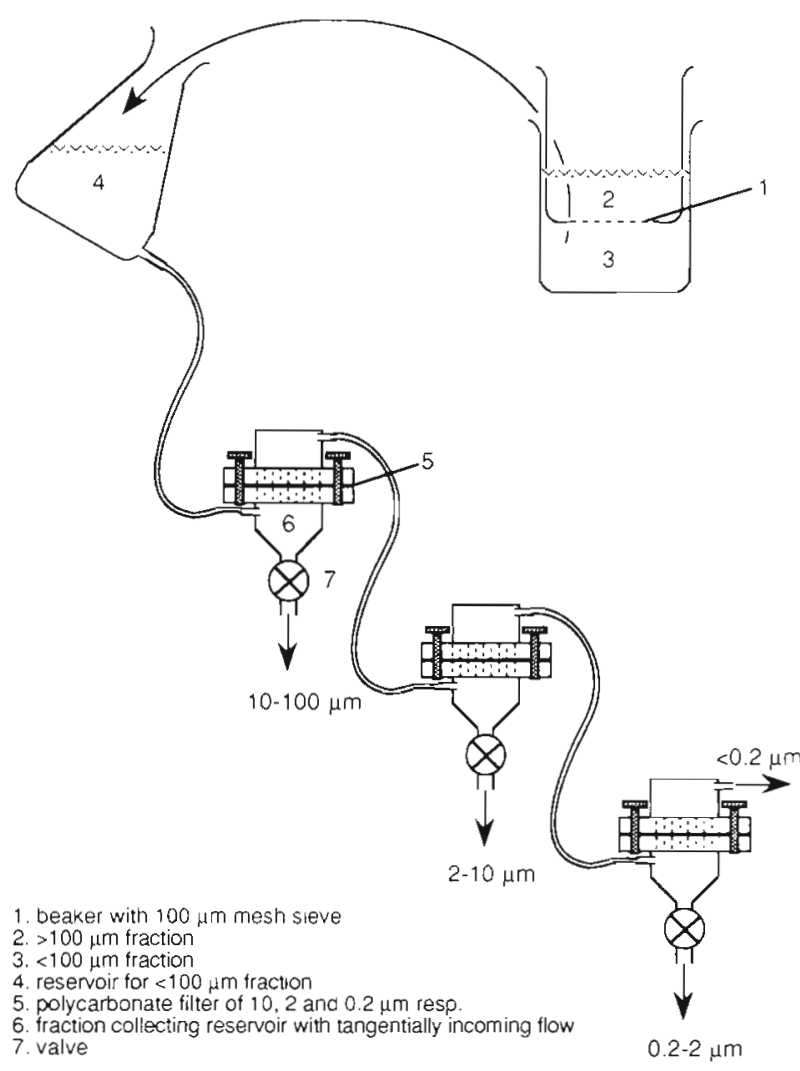

Fig. 2. Fractionation and concentration device for sea water samples, showing a cascade of tangential, reversed flow filters

of the dissolved DMSP + DMS [DMS(P)] concentration. To this end, a $4 \mathrm{ml}$ sample was stored in a $14 \mathrm{ml}$ vial, $0.4 \mathrm{ml} 10 \mathrm{~N} \mathrm{NaOH}$ was added, the vial was quickly closed with teflon-lined crimp-cap seals and stored at $4^{\circ} \mathrm{C}$. Headspace analysis of the evolved DMS was performed in the laboratory within $1 \mathrm{wk}$. No loss was detected from standards stored for more than 1 wk.

DMSP-lyase assay. A DMSP-lyase assay was applied to the particulate matter of samples taken on board. In the laboratory the deeply frozen fractions were thawed and kept on ice as much as possible during extract preparation. The buffer used for the preparation of the extract and the assay was a $50 \mathrm{mM}$ Tris buffer ( $\mathrm{pH}$ 8.5) with $5 \mathrm{mM}$ DTT. Particulate matter was harvested by centrifugation $(15 \mathrm{~min}$ at $3300 \times \mathrm{g})$, resuspended in $1 \mathrm{ml}$ Tris/DTT buffer, and disrupted with a French pressure cell at $130 \mathrm{MPa}$. Depending on the expected DMSP-lyase activity during the assay, 50 to $340 \mu \mathrm{l}$ of the crude extract was diluted with Tris/DTT-buffer The enzyme substrate DMSP.HCl was added from a $10 \mathrm{mM}$ standard, that was accurately 'preneutralised' with $5 \mathrm{mM} \mathrm{NaOH}$, giving an end concentration of $250 \mu \mathrm{M}$. Total volumes were $4.5 \mathrm{ml}$ in $14 \mathrm{ml}$ vials. DMS production was measured in the headspace (see be- low). After the assay, samples were checked for $\mathrm{pH}$. In each series control samples for abiotic DMS production were included, containing the same buffer/substrate system but replacing the extract for buffer. Samples were regularly subjected to dilution series, to check for undersaturation or inhibition: DMS production was always linearly related with extract volume. The DMSP.HCl was prepared according to Chambers et al. (1987), and checked for purity with nuclear magnetic resonance (NMR) and by comparison to DMS standards after alkaline conversion to DMS.

DMS analysis. All assays were performed in $14 \mathrm{ml}$ vials stoppered with a teflon Mininert valve. Vials were placed in the dark at $20^{\circ} \mathrm{C}$ in a constanttemperature water bath. During $60 \mathrm{~min}$, with $15 \mathrm{~min}$ intervals, DMS evolution was measured in the headspace using a Varian 3600 gas chromatograph equipped with a sulfur-specific Hall Electrolytic Conductivity Detector (Stefels \& van Boekel 1993). DMS production proved to be linear during this time period. A calibration curve was prepared from DMSP standards in seawater to which $10 \mathrm{~N} \mathrm{NaOH}$ was added (final concentration $1 \mathrm{M}$ ), giving equimolar conversion of DMSP into DMS and acrylic acid (White 1982, Dacey \& Blough 1987). Working standards were stored under the same conditions as assay samples.

Protein analysis. Protein concentrations were measured in 200 to $400 \mu$ l aliquots of the crude extracts according to the Bio-Rad protein assay, after treatment with boiling $\mathrm{NaOH}(0.5 \mathrm{M})$ for $15 \mathrm{~min}$ and subsequent centrifugation, using bovine serum albumin (BSA) as standard.

Cell counts. Cell numbers in the different fractions were counted with an inverted microscope after sedimentation of aliquots in micro plates, with magnifications up to $600 \times$. Biovolumes of the different species were computed with specially developed software, in which for each species an approximation of the form and mean size is given. Sizes are adjustable for each sample. For diatoms an approximation of the biovolume was calculated by assuming a mean plasma layer of $1 \mu \mathrm{m}$ between the cell membrane and the vacuole (Edler 1979), giving a mean biovolume of $30 \%$ of the total cell volume.

\section{RESULTS}

During the cruise the northern and offshore stations were dominated by Phaeocystis sp., whereas mainly diatom species were found in the southern and central coastal regions. This reflects a typical spring phytoplankton bloom off the Dutch coast, where an early diatom bloom is always followed by a Phaeocystis $\mathrm{sp}$ bloom (Gieskes \& Kraay 1975). 
From the samples taken, the $>100 \mu \mathrm{m}$ fraction mainly retained Phaeocystis $\mathrm{sp}$. colonies and the larger and part of the medium-sized diatom species. Although no fluorescent staining was performed on the samples, microscopy showed that this fraction was without large numbers of bacteria. The 10 to $100 \mu \mathrm{m}$ fraction was much more complex and contained medium-sized and smaller diatoms, individual Phaeocystis sp. cells, as well as most of the detritus. Only few algae passed the $10 \mu \mathrm{m}$ filter. As a biomass measure the calculated biovolume was taken to compare groups of algae within and between the $>100 \mu \mathrm{m}$ and the 10 to $100 \mu \mathrm{m}$ fractions (Table 1 ); the 2 to $10 \mu \mathrm{m}$ and 0.2 to $2 \mu \mathrm{m}$ fractions did not contain significant numbers of algae and are not included in this table. Protein measurements of the 2 largest size fractions are also given. The large range in protein to biovolume values probably reflects the combined effect of a change in species composition and variation in the detritus content of the samples. Phaeocystis sp. numbers in the original samples were calculated from the $>100 \mu \mathrm{m}$ fractions which retained $>99 \%$ of total Phaeocystis sp. numbers in all but the 2 samples with lowest Phaeocystis sp. numbers (Table 2). The results suggested that the peak of the bloom had not been reached yet. This was confirmed by data from R. L. J. Kwint \& K. J. M. Kramer (unpubl.), who reported maximum Phaeocystis sp. numbers at the near shore station $10 \mathrm{~d}$ later.

In the DMSP-lyase assay a substrate concentration of $250 \mu \mathrm{M}$ DMSP was used. Kinetic experiments with some of the samples, using DMSP concentrations up to $6 \mathrm{mM}$, showed that $250 \mu \mathrm{M}$ did not saturate the enzyme. However, during the $1 \mathrm{~h}$ assay the amount of substrate used was at most $2 \%$ of the initial concentration, resulting in activities linear in time (with typical $r^{2}$ of 0.998 ) and with enzyme concentrations. Thus, by taking care that all conditions were constant during the assay, there was no problem in comparing the samples for their activity in relation to species composition. DMSP-lyase activity proved to be highly variable in the different samples. In the 0.2 to $2 \mu \mathrm{m}$ fraction we had hoped to concentrate part of the bacterial population so that a distinction could be made between algal and bacterial DMSP-lyase activity. However, in this fraction as well as in the 2 to $10 \mu \mathrm{m}$ fractions no activity could be detected. The 10 to $100 \mu \mathrm{m}$ fractions gave low activities; highest activities were found in the $>100 \mu \mathrm{m}$ fractions. Relating DMSP-lyase activity in the crude extracts with the most abundant species found in the samples with highest activity showed a highly significant correlation with Phaeocystis sp. numbers $\left(\mathrm{r}^{2}=\right.$ $0.966, n=23$ ) (Fig. 3A). There was no correlation with

Table 1. Total biovolume, total protein content and the ratios of these parameters observed for algae in the $>100 \mu \mathrm{m}$ and 10 to $100 \mu \mathrm{m}$ fractions of surface water samples taken at various stations off the Dutch coast (see Fig. 1 for locations). From Stns W3, W5 and W6 no $>100 \mu \mathrm{m}$ fractions were taken; the T1 and T7 10 to $100 \mu \mathrm{m}$ fractions were lost

\begin{tabular}{|c|c|c|c|c|c|c|}
\hline Stn & $\begin{array}{l}\text { Fraction } \\
\quad(\mu \mathrm{m})\end{array}$ & $\begin{array}{l}\mathrm{B} 1 \mathrm{o} \\
\text { Phaeocystis sp. }\end{array}$ & $\begin{array}{l}\text { volume }\left(10^{8} \mu^{3}\right) \\
\text { Non-Phaeocystis }\end{array}$ & Total & $\begin{array}{l}\text { Total protein } \\
\qquad(\mu g)\end{array}$ & $\begin{array}{l}\text { Ratio protein biovolume } \\
\qquad\left(\mu g \mu \mathrm{l}^{-1}\right)\end{array}$ \\
\hline $\mathrm{T} 1$ & $>100$ & 8.42 & 12.96 & 21.38 & 97.53 & 45.62 \\
\hline T3 & $\begin{array}{l}>100 \\
10-100\end{array}$ & $\begin{array}{l}2.95 \\
0.028\end{array}$ & $\begin{array}{l}1.42 \\
0.872\end{array}$ & $\begin{array}{l}4.38 \\
0.90\end{array}$ & $\begin{array}{l}41.12 \\
17.72\end{array}$ & $\begin{array}{r}93.92 \\
196.72\end{array}$ \\
\hline T6 & $\begin{array}{l}>100 \\
10-100\end{array}$ & $\begin{array}{l}5.24 \\
0.035\end{array}$ & $\begin{array}{l}0.687 \\
0.427\end{array}$ & $\begin{array}{l}5.92 \\
0.46\end{array}$ & $\begin{array}{l}29.76 \\
10.66\end{array}$ & $\begin{array}{r}50.25 \\
230.75\end{array}$ \\
\hline $\mathrm{T} 7$ & $>100$ & 12.46 & 0.93 & 13.39 & 43.93 & 32.81 \\
\hline N1 & $\begin{array}{l}>100 \\
10-100\end{array}$ & $\begin{array}{l}0.244 \\
0.001\end{array}$ & $\begin{array}{c}10.6 \\
2.11\end{array}$ & $\begin{array}{r}10.79 \\
2.11\end{array}$ & $\begin{array}{l}28.01 \\
50.02\end{array}$ & $\begin{array}{r}25.95 \\
236.68\end{array}$ \\
\hline N4 & $\begin{array}{l}>100 \\
10-100\end{array}$ & $\begin{array}{l}0.114 \\
0.0004\end{array}$ & $\begin{array}{l}1.92 \\
0.715\end{array}$ & $\begin{array}{l}2.03 \\
0.72\end{array}$ & $\begin{array}{l}13.68 \\
16.13\end{array}$ & $\begin{array}{r}67.35 \\
225.48\end{array}$ \\
\hline N5 & $\begin{array}{l}>100 \\
10-100\end{array}$ & $\begin{array}{l}0.064 \\
0.003\end{array}$ & $\begin{array}{l}0.587 \\
0.158\end{array}$ & $\begin{array}{l}0.65 \\
0.16\end{array}$ & $\begin{array}{r}9.23 \\
15.91\end{array}$ & $\begin{array}{l}141.87 \\
989.57\end{array}$ \\
\hline N6 & $\begin{array}{l}>100 \\
10-100\end{array}$ & $\begin{array}{l}1.32 \\
0.015\end{array}$ & $\begin{array}{l}0.036 \\
0.091\end{array}$ & $\begin{array}{l}1.36 \\
0.11\end{array}$ & $\begin{array}{r}5.73 \\
11.51\end{array}$ & $\begin{array}{r}42.17 \\
1089.50\end{array}$ \\
\hline N8 & $\begin{array}{l}>100 \\
10-100\end{array}$ & $\begin{array}{l}2.01 \\
0.012\end{array}$ & $\begin{array}{l}0.015 \\
0.013\end{array}$ & $\begin{array}{l}2.02 \\
0.025\end{array}$ & $\begin{array}{l}23.87 \\
12.62\end{array}$ & $\begin{array}{c}118.0 \\
5060.84\end{array}$ \\
\hline W1 & $\begin{array}{l}>100 \\
10-100\end{array}$ & $\begin{array}{l}0.063 \\
0.005\end{array}$ & $\begin{array}{l}6.24 \\
4.5\end{array}$ & $\begin{array}{l}6.3 \\
4.5\end{array}$ & $\begin{array}{l}20.26 \\
29.55\end{array}$ & $\begin{array}{l}32.15 \\
65.61\end{array}$ \\
\hline W3 & $10-100$ & 0 & 1.72 & 1.72 & 35.49 & 206.54 \\
\hline W5 & $10-100$ & 0 & 1.26 & 1.26 & 22.49 & 178.01 \\
\hline W6 & $10-100$ & 0 & 0.017 & 0.017 & 4.24 & 2495.88 \\
\hline W7 & $\begin{array}{l}>100 \\
10-100\end{array}$ & $\begin{array}{l}0.281 \\
0.003\end{array}$ & $\begin{array}{l}0.523 \\
0.477\end{array}$ & $\begin{array}{l}0.8 \\
0.48\end{array}$ & $\begin{array}{l}10.34 \\
10.18\end{array}$ & $\begin{array}{l}128.82 \\
212.36\end{array}$ \\
\hline
\end{tabular}


Table 2. Phaeocystis sp. cell numbers at the various sampling stations as calculated from the $>100 \mu \mathrm{m}$ fraction and dissolved DMSP + DMS concentrations in the corresponding sample. nd $=$ not detectable

\begin{tabular}{|ccc|}
\hline Stn & $\begin{array}{c}\text { Phaeocystis sp. } \\
\text { cell numbers }\left(10^{6} \mathrm{l}^{-1}\right)\end{array}$ & $\begin{array}{c}\text { Dissolved } \\
\text { DMSP + DMS (nM) }\end{array}$ \\
\hline T1 & 15.442 & 25 \\
T3 & 8.018 & 31 \\
T6 & 10.153 & 38 \\
T7 & 26.576 & 26 \\
N1 & 0.237 & 1 \\
N4 & 0.118 & 1 \\
N5 & 0.063 & 1 \\
N6 & 2.861 & 17 \\
N8 & 4.089 & 9 \\
W1 & 0.063 & 6 \\
W3 & nd & nd \\
W5 & nd & nd \\
W6 & nd & nd \\
W7 & 0.590 & 11 \\
\hline
\end{tabular}

any of the other species, nor with total diatom numbers or total diatom biovolume (Fig. 3B to $F$ ). The relation with total protein content gave a slightly higher correlation (Fig. 3G), reflecting the presence of Phaeocystis sp. cells in some of the samples with high protein content. On the other hand, the sample with second highest protein content exhibited hardly measurable lyase activity, and proved to be mainly composed of detritus.

Dissolved DMS $(\mathrm{P})$ concentrations were measured in the $<0.2 \mu \mathrm{m}$ fraction. Because head space analysis was used, the detection limit was rather high (1 $\mathrm{nM}$ ). To avoid high pressure on cells during filtration and subsequent disruption and release of intracellular DMSP, a reversed filtration technique was choosen (Fig. 2). Although no direct check on leakage of DMSP from cells was done, the very low DMS(P) values in the $<0.2 \mu \mathrm{m}$ fraction compared to total DMS(P) values from samples taken directly from the bucket (data not shown) indicated that no lysis of cells had occurred during the filtration procedure. Checks on loss of dissolved DMSP due to adsorption in the filtration unit gave similar concentrations for all compartments. Ratios of total DMS(P) to dissolved DMS(P) were on the order of 8 to 20 . This is in good agreement with Kwint \& Kramer (unpubl.), who measured ratios of 6 to 10 in surface water samples from the same area. Dissolved DMS(P) was detected in samples with Phaeocystis sp. cells only (Table 2).

\section{DISCUSSION}

A DMSP-lyase assay was applied to natural sea water samples. The large variety in species composi-
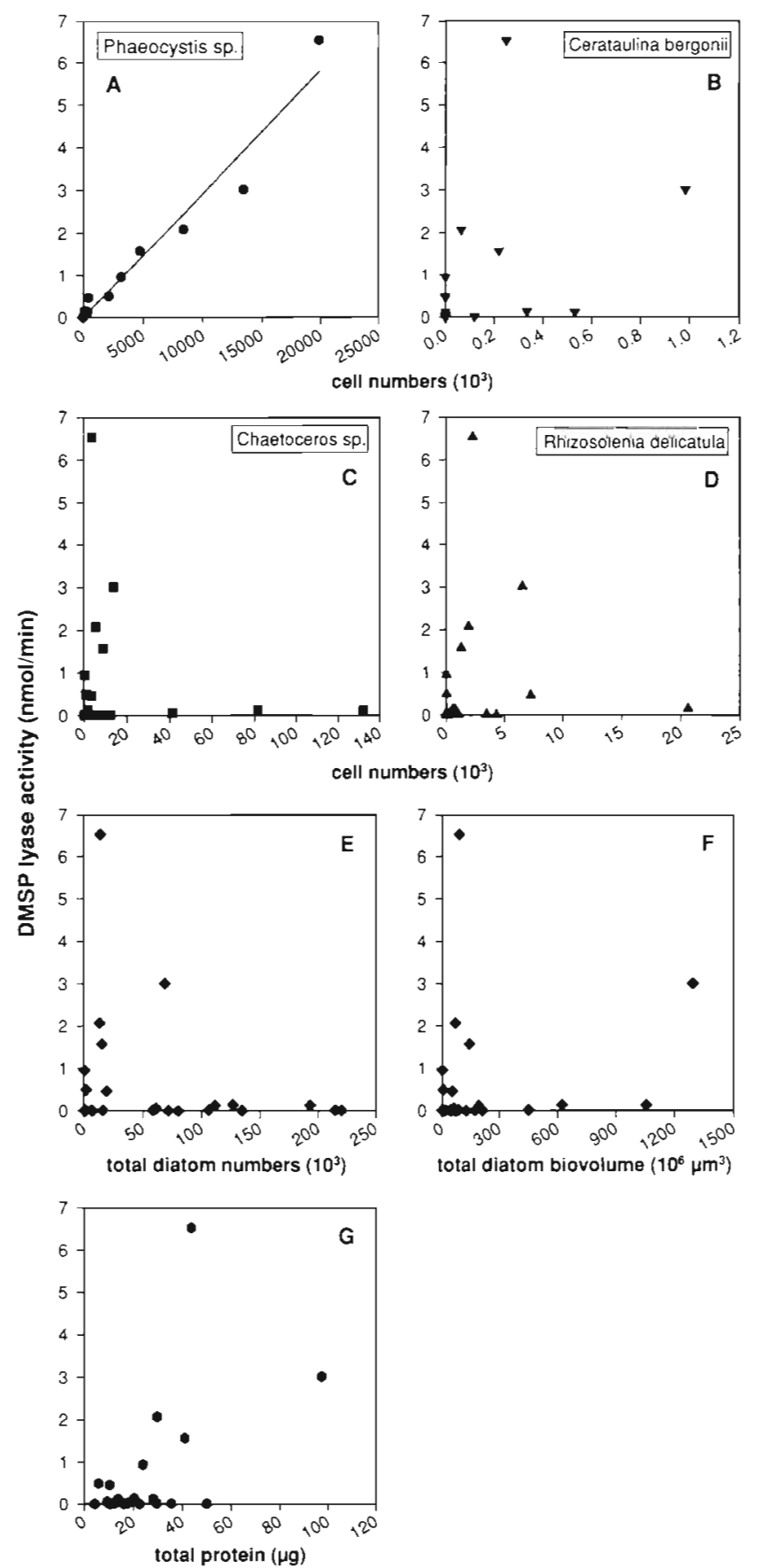

Fig. 3. DMSP-lyase activity in $1 \mathrm{ml}$ crude extract, using a substrate concentration of $250 \mu \mathrm{M}$ DMSP, in relation to numbers of (A) Phaeocystis sp., (B) Cerataulina bergonii, (C) Chaetoceros sp., (D) Rhizosolenia delicatula, (E) total diatom numbers, (F) total diatom biovolume and (G) total protein content. The equation of the regression line for Phaeocystis sp. is $y=0.2905 \times 10^{-6} \mathrm{x}+0.0105, \mathrm{r}^{2}=0.9660, \mathrm{n}=23$

tion in these samples provided us with the opportunity to test natural plankton assemblages for their DMSP. lyase activity in relation to species composition. A highly significant correlation between DMSP-lyase activity 
and Phaeocystis sp. cell numbers was found, whereas other species failed to show any such correlation.

Two points require further consideration. First, the assay was developed with crude extracts of Phaeocystis sp. cells (Stefels unpubl.), and one can argue that this might obscure the possible activity of other DMSPlyases present either in other algal species or in bacteria. To avoid this problem the assay was performed at $\mathrm{pH}$ 8.5: this $\mathrm{pH}$ is far from optimal for the Phaeocystis DMSP-lyase, which has a more alkaline optimum, but high enough to give a $50 \%$ activity of this enzyme (Stefels unpubl.). When comparing the assays used by Ishida (1968) and Cantoni \& Anderson (1956) for other algal species with the assay used in this study, it appears unlikely that the latter would cause strong inactivation of all other DMSP-lyases present. Second, highest activities were found in the $>100 \mu \mathrm{m}$ fractions, in which Phaeocystis sp. colonies were trapped. The possibility that these colonies were associated with large numbers of DMSP-converting bacteria containing the DMSP-lyase activity could not be excluded unambiguously due to lack of bacterial counts, but was rejected on the basis of the following arguments. (1) If bacteria exhibit the main part of the enzyme activity, the highly significant correlation between Phaeocystis sp. numbers and DMSP-lyase activity, and the $y$-axis intercept not being significantly different from zero (Fig. 3A), would imply a constant ratio of Phaeocystis sp. cells and these bacteria. However, healthy cells produce little extracellular DMSP (Stefels \& van Boekel 1993), thus being a poor substrate to select bacteria on. A more prominent role for bacteria is to be expected during the senescent phase of the bloom, when colonies disintegrate with subsequent release of large amounts of organic matter. Large numbers of bacteria indeed are only found during late stages of Phaeocystis sp. blooms (Verity et al. 1988, Billen et al. 1990, van Boekel et al 1992, Thingstad \& Billen 1994). The actual contribution of DMSP as a substrate for bacteria within the bulk of released organic matter is unknown. A constant ratio between Phaeocystis sp. cells and DMS-producing bacteria therefore appears unlikely. (2) If bacteria were active in cleaving DMSP in our samples, one would also expect to find bacterial DMSP-lyase activity associated with the detritus that is found in samples with large numbers of Phaeocystis $\mathrm{sp}$. and which is retained in the 10 to $100 \mu \mathrm{m}$ fraction. In this fraction, however, activities were near the limit of detection. Therefore, it was concluded that the DMSPlyase activity measured can be attributed solely to Phaeocystis sp. cells.

With respect to the possible role of Phaeocystis sp. in the release of DMS to the atmosphere, it is interesting to compare the potential DMS production rates by Phaeocystis sp. cells with the main abiotic loss factors such as fluxes of DMS to the atmosphere and photochemical oxidation. Calculations of DMS production in the water column were done according to the following equation.

$$
P_{\mathrm{wc}}=P_{\mathrm{ph}} \times N \times D \times 1440
$$

where $P_{w c}$ is the DMS production rate over the water column in $\mu \mathrm{mol} \mathrm{m} \mathrm{m}^{-2} \mathrm{~d}^{-1} ; P_{\mathrm{ph}}$ is the DMS production by Phaeocystis sp. cells in nmol min ${ }^{-1} \mathrm{cell}^{-1}, N$ is the number of Phaeocystis sp. cells $1^{-1}$ (Table 2), and $D$ is the depth of the mixing layer in $m$, over which a homogenious distribution of the plankton can be assumed. $P_{\mathrm{ph}}$ was calculated from experiments with exponentially growing cells, in which effects of $\mathrm{pH}$ and temperature were measured on the DMSP-lyase activity in whole cells (Stefels unpubl.). Assuming linear lyase activity in the lower substrate concentration ranges, these experiments yielded activities of $3.5 \times 10^{-11} \times$ [DMSP] at the in situ temperature of $8^{\circ} \mathrm{C}$, an estimate which is confirmed in several other experiments with whole cells (unpubl.), and which is in good agreement with activities published earlier (Stefels \& van Boekel 1993). The dissolved DMSP concentration is expressed in nM and assumed to be $75 \%$ of the total DMS(P) concentration measured in the $<0.2 \mu \mathrm{m}$ fraction (Table 2 ). This percentage was estimated in more detailed chemical studies performed in the same area during the same period (Kwint \& Kramer unpubl.), and is in accordance with data from around the British mainland (Turner et al. 1988). Turner et al. (1989) monitored a Phaeocystis sp. bloom in the Southern Bight of the North Sea and measured dissolved DMSP concentrations approximately 10 times higher than DMS concentrations. Therefore the $75 \%$ used here may be a slight underestimation. For $D$ a mean depth of $5 \mathrm{~m}$ was taken, although fluorescence and transmittance measurements made on board, sometimes showed homogeneity of the water column over $15 \mathrm{~m}$. Homogeneous distributions of Phaeocystis sp. over the water column were confirmed by studies of R. Riegman (pers. comm.).

The resulting potential DMS production rates are given in Fig. 4. Highest values were calculated for the Texel track (all ' $\mathrm{T}$ ' stations in Fig. 1), in the northern part of the study area, where the Phaeocystis sp. bloom was most abundant, ranging from 47 to $131 \mu \mathrm{mol} \mathrm{m} \mathrm{m}^{-2}$ $\mathrm{d}^{-1}$ We compared these production rates with the main abiotic loss factors, flux to the atmosphere and photochemical oxidation. The mean flux of DMS to the atmosphere in this northern area can be calculated following Liss \& Merlivat (1986): flux $=k_{w} \times \Delta C$. During the cruise the mean wind speed was $5 \mathrm{~m} \mathrm{~s}^{-1}$, giving a corresponding transfer velocity $k_{w}$ of $4.6 \mathrm{~cm} \mathrm{~h}^{-1}$ (Liss \& Merlivat 1986). Because we were not able to measure DMS concentrations accurately, an average of $15 \mathrm{nM}$ was assumed, as measured at that time near our 


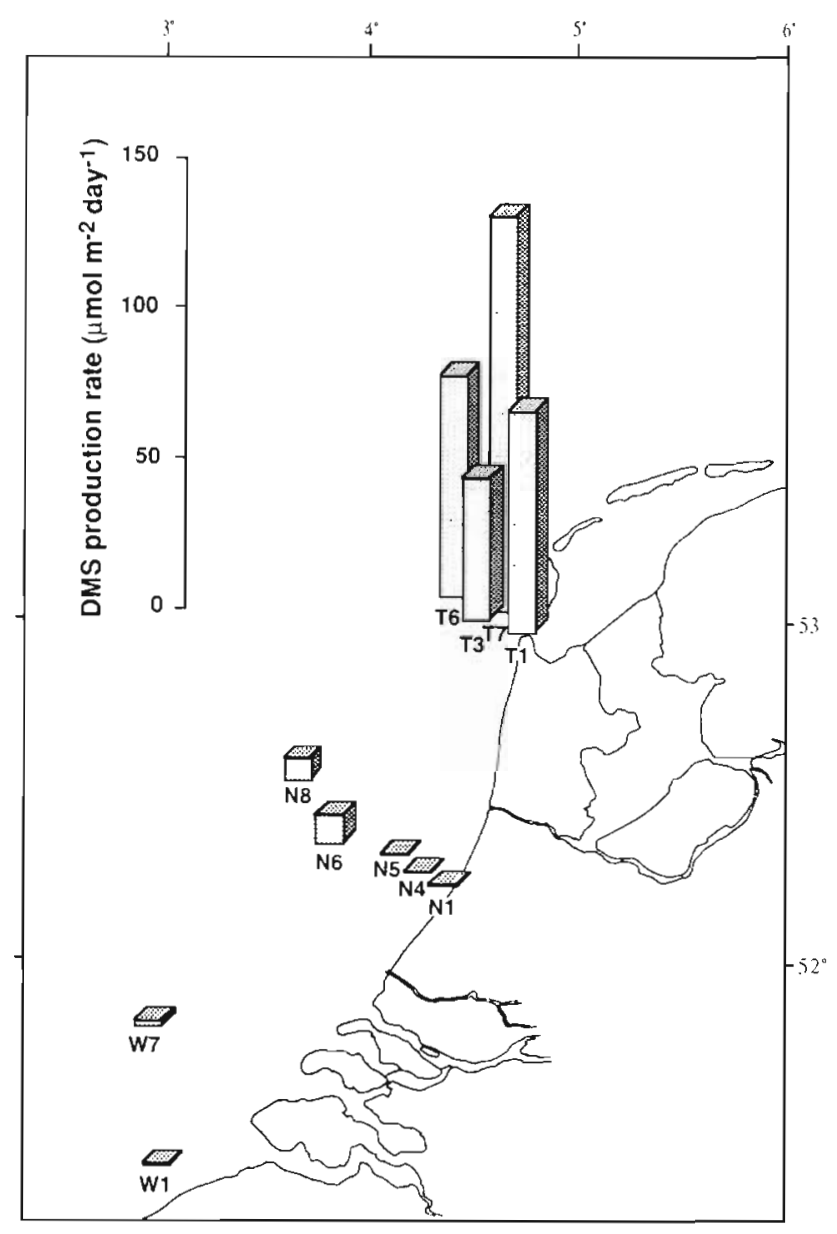

Fig. 4. Phaeocystis sp. Potential DMS production rates in Dutch coastal waters during the spring bloom of 1993, calculated using extrapolated activities found in exponentially growing cultures; a mixing depth of $5 \mathrm{~m}$; dissolved DMSP concentrations equalling $75 \%$ of the DMSP + DMS measurements in the $<0.2 \mu \mathrm{m}$ fractions of the corresponding samples

inshore station by Kwint \& Kramer (unpubl.). Thus a flux of $16.6 \mu \mathrm{mol} \mathrm{m} \mathrm{m}^{-2} \mathrm{~d}^{-1}$ was calculated. Concerning photochemical oxidation of DMS to DMSO, Brimblecombe \& Shooter (1986) calculated a half life time for DMS in coastal waters of $8 \mathrm{~h}$, with total loss rates presumably comparable with losses by air-sea exchange. Total abiotic loss rates can therefore be estimated to be approximately $30 \mu \mathrm{mol} \mathrm{m} \mathrm{m}^{-2} \mathrm{~d}^{-1}$. Compared with the potential DMS production by Phaeocystis sp. this is in the same range; even a 1.5 to 4.5 times overproduction of DMS can be calculated, potentially available for bacterial consumption. Considering the conservative estimations of the parameters used, production may even be higher. Previously, rates of production and consumption of DMS have been studied with the chloroform inhibition technique (Kiene \& Bates 1990 . Kiene \& Service 1991, Bates et al. 1994). These studies also suggest that loss by air-sea exchange is minor when compared with microbial production and consumption rates of DMS. The chloroform inhibition technique does not distinguish between bacterial and algal production of DMS.

In field situations, where low dissolved DMSP concentrations prevail, the affinity of the enzyme system for DMSP has to be taken into account, and it is hard to judge whether bacterial or algal DMSP-lyases will dominate, since conversion rates at low substrate concentrations have not been measured yet. Recently, Ledyard \& Dacey (1994) isolated a bacterium from the Sargasso Sea, in which uptake of DMSP took place prior to cleavage. They found that the rate of DMS production showed a sigmoidal dependence on extracellular DMSP at low concentrations. At 50 nM DMSP this resulted in a DMS production rate of ca $0.05 \mathrm{fmol}$ cell ${ }^{-1} \mathrm{~h}^{-1}$. Experiments with whole cells and crude extracts of axenic Phaeocystis sp. cultures gave indications for an extracellular location of the DMSP-lyase (Stefels unpubl.), making it unlikely that membrane transport interferes with DMSP conversion. There were no indications of a deviation from linearity of lyase activity in the nonsaturating substrate range. Therefore, we assumed linearity, resulting in a production rate at $50 \mathrm{nM}$ DMSP of $0.105 \mathrm{fmol} \mathrm{cell}^{-1} \mathrm{~h}^{-1}$ for cells from the exponential growth phase at $8^{\circ} \mathrm{C}$. If the kinetic parameters of the Sargasso strain are the same as those of bacteria from more eutrophied areas, a population density of $10^{7}$ to $10^{8}$ cells $1^{-1}$ of these bacteria will give DMS production rates comparable with those from Phaeocystis sp., as found in our samples. Although the results of our study do not exclude bacterial activity, it appears reasonable to assume that during the early stages of a Phaeocystis sp. bloom, this alga is the main DMS-producing species. In the literature, a close correlation is found between Phaeocystis sp. abundance and high DMS concentrations in the sea water (Barnard et al. 1984, Holligan et al. 1987, Gibson et al. 1990). Liss et al. (1993) showed large seasonal variations of DMS in the southern North Sea, with a maximum in front of the Dutch coast during the Phaeocystis sp. bloom. Our study has made it plausible that Phaeocystis sp. itself plays an important role in this production of DMS.

In summary, this study shows that, during an early spring bloom in the North Sea, Phaeocystis sp. exhibits a very active DMSP-lyase, specific for this species, causing a potential DMS production in excess of abiotic loss factors such as flux to the atmosphere and photochemical oxidation, leaving 35 to $75 \%$ of DMS for bacterial consumption. It was only possible to give a rough estimate of the importance of algal DMS production. Environmental conditions may change rapidly, leading to deviations in the abiotic as well as biotic production and consumption terms of DMS, including the possible demethylation of DMSP (Kiene 
\& Service 1991, Bates et al. 1994). For a better understanding of the fate of the total DMSP-sulfur pool in a Phaeocystis sp. bloom, the relative importance of all processes involved should be investigated simultaneously and on a daily basis.

Acknowledgements. The authors thank the participants of the PMNS project for providing the opportunity to join the cruise and the crew of RV 'Pelagia' for their co-operation. Peter Quist and Marc van der Maarel of the Department of Microbiology of the University of Groningen are gratefully acknowledged for providing a steady supply of DMSP. TRIPOS kindly let me use their plankton counting program; Reinoud Koeman helped with the analysis of the data. The remarks by Wim van Boekel greatly improved the clarity of the manuscript. This study has been performed within the framework of the NOP project 'Formation and air/sea exchange of DMS from marine sources', supported by the Dutch government (NOLK/026/90).

\section{LITERATURE CITED}

Andreae MO (1990) Ocean-atmosphere interactions in the global biogeochemical sulfur cycle. Mar Chem 30:1-29

Barnard WR, Andreae MO, Iverson RL (1984) Dimethylsulfide and Phaeocystis poucheli in the southeastern Bering sea. Cont Shelf Res 3:103-113

Bates TS, Kiene RP, Wolfe GV, Matrai PA, Chavez FP, Buck KR, Blomquist BW, Cuhel RL (1994) The cycle of sulfur in surface seawater of the northeast Pacific. J geophys Res 99(C4):7835-7843

Baumann MEM, Brandini FP, Staubes R (1994) The influence of light and temperature on carbon-specific DMS release by cultures of Phaeocystis antarctica and three antarctic diatoms. Mar Chem 45:129-136

Billen G, Joiris C, Meyer-Reil L, Lindeboom H (1990) Role of bacteria in the North Sea ecosystem. Neth J Sea Res 26: 265-293

Blunden G, Smith B, Irons MW, Yang M, Roch OG, Patel AV (1992) Betaines and tertiary sulphonium compounds from 62 species of marine algae. Biochem Syst Ecol 20(4): $373-388$

Brimblecombe P. Shooter D (1986) Photo-oxidation of dimethylsulfide in aqueous solution. Mar Chem 19:343-353

Cadée GC, Hegeman J (1986) Seasonal and annual variation in Phaeocystis pouchetii (Haptophyceae) in the westernmost inlet of the Wadden Sea during the 1973 to 1985 period. Neth J Sea Res 20:29-36

Cantoni GL, Anderson DG (1956) Enzymatic cleavage of dimethylpropiothetin by Polysiphonia lanosa. J biol Chem 222:171-177

Chambers ST, Kunin CM, Miller D, Hamada A (1987) Dimethylthetin can substitute for glycine betaine as an osmoprotectant molecule for Escherichia coli. J Bacteriol $169: 4845-4847$

Charlson RJ, Lovelock JE, Andreae MO, Warren, SG (1987) Oceanic phytoplankton, atmospheric sulfur, cloud albedo and climate. Nature 326:655-661

Charlson RJ, Wigley TML (1994) Sulfate aerosol and climate change. Scient Am 270 (2):28-35

Dacey JWH, Wakeham SG (1986) Oceanic dimethylsulfide production during zooplankton grazing. Science 233 $1314-1316$

Dacey JWH, Blough N (1987) Hydroxide decomposition of dimethyl-sulfoniopropionate to form dimethylsulfide.
J geophys Res Lett 14:1246-1249

Davidson AT, Marchant HJ (1992) The biology and ecology of Phaeocystis (Prymnesiophyceae). In: Round FE, Chapman DJ (eds) Progress in phycological research 8. Biopress Ltd, Bristol, p 1-45

Dickson DMJ, Kirst GO (1987a) Osmotic adjustment in marine eukaryotic algae. the role of inorganic ions, quaternary ammonium, tertiary sulphonium and carbohydrate solutes. I. Diatoms and a rhodophyte. New Phytol 106:645-655

Dickson DMJ, Kirst GO (1987b) Osmotic adjustment in marine eukaryotic algae: the role of inorganic ions, quaternary ammonium, tertiary sulphonium and carbohydrate solutes. II. Prasinophytes and haptophytes. New Phytol 106:657-666

Edler L (1979) Recommendations for marine biological studies in the Baltic Sea: phytoplankton and chlorophyll. Baltic Marine Biologists WG 9, Publ The National Swedish Environmental Protection Board, Malmö

Fitzgerald JW (1991) Marine aerosols: a review. Atmos Environ 25:533-545

Gibson JAE, Garrick RC, Burton HR, McTaggart AR (1990) Dimethylsulfide and the alga Phaeocystis pouchetii in antarctic coastal waters. Mar Biol 104:339-346

Gieskes WWC, Kraay GW (1975) The phytoplankton spring bloom in Dutch coastal waters of the North Sea. Neth J Sea Res 9(2):166-196

Holligan PM, Turner SM, Liss PS (1987) Measurements of dimethyl sulphide in frontal regions. Cont Shelf Res 7: 213-224

Ishida Y (1968) Physiologica] studies on the evolution of dimethylsulfide. Mem Coll Agric Kyoto Univ 94:47-82

Keller MD, Bellows WK, Guillard RRL (1989). Dimethyl sulfide production in marine phytoplankton. In: Saltzman ES, Cooper WJ (eds.) Biogenic sulfur in the environment ACS Symp Ser 393, American Chemical Society, Washington, DC, p 167-182

Kiene RP (1990) Dimethylsulfide production from dimethylsulfonio-propionate in coastal seawater samples and bacterial cultures. Appl environ Microbiol 56:3292-3297

Kiene RP (1992) Dynamics of dimethyl sulfide and dimethylsulfonio-propionate in oceanic water samples. Mar Chem $37: 29-52$

Kiene RP, Bates TS (1990) Biological removal of dimethyl sulfide from sea water. Nature 345:702-705

Kiene RP, Service SK (1991) Decomposition of dissolved DMSP and DMS in estuarine waters: dependence on temperature and substrate concentration. Mar Ecol Prog Ser $76: 1-11$

Lancelot C, Billen G, Sournia A, Weisse T, Colijn F, Veldhuis MJW, Davies A, Wassmann P (1987). Phaeocystis blooms and nutrient enrichment in the continental coastal zones of the North Sea. Ambio 16(1):38-46

Lawrence MG (1993) An empirical analysis of the strength of the phytoplankton-dimethylsulfide-cloud-climate feedback cycle. J geophys Res 98(D11):20663-20673

Leck C, Larsson U, Bảgander LE, Johansson S, Hajdu S (1990) Dimethyl sulfide in the Baltic Sea: annual variability in relation to biological activity. J geophys Res 95(C3): 3353-3363

Ledyard KM. Dacey JWH (1994) Dimethylsulfide production from dimethyl-sulfoniopropionate by a marine bacterium. Mar Ecol Prog Ser 110:95-103

Liss PS, Malin G, Turner SM, Holligan PM (1994). Dimethyl sulphide and Phaeocystis: A review. In: Lancelot C, Wassmann P (eds.) The ecology of Phaeocystis-dominated systems. J mar Syst 5:41-53 
Liss PS, Merlivat L (1986) Air-gas exchange rates: introduction and synthesis. In: Buat-Menard $P$ (ed.) The role of airsea exchange in geochemical cycling. Reidel, Dordrecht, p $113-127$

Liss PS, Watson AJ, Liddicoat Ml, Malin G, Nightingale PD, Turner SM, Upstill-Goddard RC (1993). Trace gases and air-sea exchange. Phil Trans R Soc London A 343:531-541

Malin G, Liss PS, Turner SM (1994): Dimethyl sulfide: production and atmospheric consequences. In: Green JC, Leadbeater BSC (eds) The haptophyte algae. Systematics Association Spec Vol 51. Clarendon Press, Oxford, p 303-320

Malin G, Turner SM, Liss PS (1992) Sulfur: the plankton/ climate connection. J Phycol 28:590-597

Matrai PA, Keller MD (1993) Dime thylsulfide in a large-scale coccolithophore bloom in the Gulf of Maine. Cont Shelf Res 13 (8/9):831-843

Reed RH (1983) Measurement and osmotic significance of $\beta$-dimethyl-sulfoniopropionate in marine macroalgae. Mar Biol Lett 4:173-178

Riegman R, Noordeloos AAM, Cadée GC (1992) Phaeocystis blooms and eutrophication of the continental zones of the North Sea. Mar Biol 112:479-484

Smith WO Jr, Codispoti LA, Nelson DM, Manley T, Buskey EJ, Niebauer HJ, Cota GF (1991) Importance of Phaeocystis blooms in the high-latitude ocean carbon cycle. Nature 352:514-516

Stefels J, van Boekel WHM (1993) Production of DMS from dissolved DMSP in axenic cultures of the marine phytoplankton species Phaeocystis sp. Mar Ecol Prog Ser 97 : $11-18$

This article was submitted to the editor
Thingstad F, Billen G (1994). Microbial degradation of Phaeocystis material in the water column. In: Lancelot C, Wassmann $\mathrm{P}$ (eds.) Ecology of Phaeocystis-dominated ecosystems. J mar Syst 5(1):55-65

Turner SM, Malin G, Liss PS (1989). Dimethyl sulfide and (dimethylsulfonio)propionate in European coastal and shelf waters. In: Saltzman ES, Cooper WJ (eds) Biogenic sulfur in the environment. ACS Symp Ser 393. American Chemical Society, Washington, DC, p 183-200

Turner, SM, Malin G, Liss PS, Harbour DS, Holligan PM (1988) The seasonal variation of dimethylsulfoniopropionate concentrations in near-shore waters. Limnol Oceanogr 33 : $364-375$

Vairavamurthy A, Andreae MO, Iverson RL (1985). Biosynthesis of dimethyl sulfide and dimethylpropiothetin by Hymenomonas carterae in relation to sulfur source and salinity variations. Limnol Oceanogr 30:59-70

van Boekel WHM, Hansen FC, Riegman R, Bak RPM (1992) Lysis-induced decline of a Phaeocystis spring bloom and coupling with the microbial foodweb. Mar Ecol Prog Ser $81: 269-276$

Verity PG, Villareal TA, Smayda TJ (1988). Ecological investigations of blooms of colonial Phaeocystis pouchetii. II. The role of life-cycle phenomena in bloom termination. J Plankton Res 10(4):749-766

White RH (1982). Analysis of dimethyl sulfonium compounds in marine algae. J mar Res 40:529-536

Wolfe GV, Sherr EB, Sherr BF (1994). Release and consumption of DMSP from Emiliania huxleyi during grazing by Oxyrrhis marina. Mar Ecol Prog Ser 111:111-119

Manuscript first received: August 28, 1994

Revised version accepted: February 21, 1995 